\title{
Composition and Diversity of Fungal Decomposers of Submerged Wood in Two Lakes in the Brazilian Amazon State of Pará
}

\author{
Eveleise Samira Martins Canto ${ }^{1}$, ${ }^{1,2}$ Ana Claúdia Alves Cortez, ${ }^{3}$ Josiane Santana Monteiro, ${ }^{4}$ \\ Flavia Rodrigues Barbosa, ${ }^{5}$ Steven Zelski $\mathbb{D}^{6}{ }^{6}$ and João Vicente Braga de Souza ${ }^{3}$ \\ ${ }^{1}$ Programa de Pós-Graduação da Rede de Biodiversidade e Biotecnologia da Amazônia Legal-Bionorte, \\ Manaus, Amazonas, Brazil \\ ${ }^{2}$ Universidade Federal do Oeste do Pará, UFOPA, Santarém, Pará, Brazil \\ ${ }^{3}$ Instituto Nacional de Pesquisas da Amazônia, INPA, Laboratório de Micologia, Manaus, Amazonas, Brazil \\ ${ }^{4}$ Museu Paraense Emilio Goeldi-MPEG, Belém, Pará, Brazil \\ ${ }^{5}$ Universidade Federal de Mato Grosso, UFMT, Sinop, Mato Grosso, Brazil \\ ${ }^{6}$ Miami University, Department of Biological Sciences, Middletown, OH, USA
}

Correspondence should be addressed to Eveleise Samira Martins Canto; eveleisesamira@hotmail.com and Steven Zelski; zelskise@miamioh.edu

Received 25 August 2019; Revised 20 February 2020; Accepted 4 March 2020; Published 9 April 2020

Academic Editor: Giuseppe Comi

Copyright (c) 2020 Eveleise Samira Martins Canto et al. This is an open access article distributed under the Creative Commons Attribution License, which permits unrestricted use, distribution, and reproduction in any medium, provided the original work is properly cited.

\begin{abstract}
Aquatic ecosystems in tropical forests have a high diversity of microorganisms, including fungi, which are important decomposers of submerged wood. Despite the importance of their role in decomposition, research concerning the diversity of freshwater fungi from Brazilian Amazonian environments is scarce. The aim of this work was to describe the composition and diversity of fungi present on submerged wood in two lakes of the Brazilian Amazon (State of Pará). Fragments of decaying wood (30 samples per lake) were collected from the Lakes Juá and Maicá. The wood samples were inspected for 6 months in the presence of fungal reproductive structures. Fungi observed in the wood were identified morphologically. Twenty-three taxa were identified in the Lake Juá (10 sexual and 13 asexual) and 26 taxa in the Lake Maicá (17 sexual, 9 asexual). ITS sequences were obtained for 14 taxa to aid in identification. In the Lakes Juá and Maicá, the diversity indices were H’: 2.6514 and H’: 2.8174, respectively. The Sørensen index of the fungal communities in the studied lakes was 0.3673 . This study is the first to describe the fungal biodiversity of two important aquatic environments in Pará, Brazil.
\end{abstract}

\section{Introduction}

Freshwater fungi include species that inhabit water for all or part of their life cycle or any species adapted to colonize predominantly aquatic or semiaquatic substrates in nature [1]. These organisms serve as key agents in the decomposition of submerged dead plant material. Fungal biomass is a source of nutrition for other organisms in aquatic ecosystems $[2,3]$. Fungal enzymatic activity also modifies plant substrates to make them more palatable to invertebrate shredders and scrapers [4].

Freshwater ascomycetes are a group of fungi known to actively participate in the decomposition of submerged woody debris $[5,6]$. This group is polyphyletic, with the majority of species belonging to the subphylum Pezizomycotina in the classes Leotiomycetes, Sordariomycetes, and Dothideomycetes [2, 7]. Members of the Eurotiomycetes [8] and Orbiliomycetes [9] are less common. Shearer and Raja [10] reported that freshwater ascomycetes are distributed in relatively few orders: Helotiales, Pleosporales, Sordariales, Savoryellales, Microascales, Eurotiales, and Jahnulales. The number of known taxa has increased in recent years due to broader sampling and the use of molecular methods for identification $[11,12]$.

The Amazon basin is arguably the most complex network of aquatic habitats on the planet [13]. This vast region 
contains a variety of aquatic environments that include large rivers, lakes, swamps, and seasonally inundated floodplains $[13,14]$. Aquatic ecosystems can be roughly classified into three main types: clear waters [15], white waters [16], and black waters [14, 17]. Water characteristics such as temperature, dissolved oxygen, and amount of organic matter may influence the diversity of freshwater fungal species [18]. The first published studies of freshwater fungi in Amazonian waters (Peru) were conducted by Matsushima in white water rivers [19]. More recent studies have described new species of ascomycetes in the Peruvian Amazon [20-24] and in the Brazilian states of Pará $[25,26]$ and Amazonas [27, 28]. In general, the microbial community of the Amazon region is still underexplored, and studies describing the diversity and ecology of fungi in the Amazon region are urgently needed. Therefore, we sought to investigate new environments such as the Tapajós River, one of the largest clear water tributaries of the Amazon River [17]. The present work aimed to describe the composition and diversity of fungi present on submerged decomposing wood in two lakes in the Tapajós River basin near Santarém, in the Brazilian state of Pará.

\section{Materials and Methods}

2.1. Study Sites. Samples of submerged wood were collected from Lake Juá $\left(2^{\circ} 25^{\prime} 57^{\prime \prime} \mathrm{S}, 54^{\circ} 46^{\prime} 39^{\prime \prime} \mathrm{W}\right)$ and Lake Maicá $\left(2^{\circ} 27^{\prime} 29.0^{\prime \prime} \mathrm{S}, 54^{\circ} 40^{\prime} 10.8^{\prime \prime} \mathrm{W}\right)$ and, essentially, the embayment of the lower Tapajós and Amazon Rivers, respectively. Lake Juá receives water that drains from a stream and the Tapajós. Lake Maicá is a mix of surface drainages and the white water of the Amazon River [14] (Figures 1, 2(a), and 2(b)).

2.2. Water Characterization. Physicochemical variables were measured using a ProfiLine 197i WTW multiparameter probe (Wellheim, Germany). Temperature $\left({ }^{\circ} \mathrm{C}\right), \mathrm{pH}$, electrical conductivity $(\mu \mathrm{S})$, dissolved oxygen concentration $(\mathrm{mg} / \mathrm{L})$, and turbidity (NTU) were recorded for each sample collection.

2.3. Sample Collection. A single collection was made at each location in Lake Juá in October 2017 and in Lake Maicá in November 2017. At each site, 30 submerged wood fragments that showed signs of active decomposition were collected. The lengths of the samples ranged from 6 to $22 \mathrm{~cm}$ and diameters ranged from 6 to $15 \mathrm{~cm}$ (Figure 2(c)). These substrates were transported in sealable plastic bags $(20 \mathrm{~cm} \times 10 \mathrm{~cm})$, with a small amount of local water, to the Laboratory of Multidisciplinary Teaching in Applied Biology-Labio, Universidade Federal do Oeste do Pará (UFOPA). In the laboratory, the samples were gently rinsed with running water, placed in moist chambers (plastic boxes with moist paper towels), and incubated at room temperature with $12 / 12 \mathrm{~h}$ light/dark conditions.

2.4. Isolation and Identification of Fungi Present on Submerged Wood. Every ten days, for six months, a Stemi DV4 stereomicroscope (Zeiss) was used to search for fungal structures on the collected wood samples. The structures found were transferred, with dissection needles, to microscope slides containing distilled water. The identification of sexual ascomycetes was performed based on the micromorphology of ascomata, hamathecium, asci, and ascospores using an Axioskop 40 microscope (Zeiss) as described previously $[22,29,30]$. Aqueous lactophenol cotton blue solution was used to determine the staining reactions of the apical ascus apparatus. Asexual ascomycetes were identified by investigating the types of conidiogenesis, conidiophore, and conidia, using an Axioskop 40 microscope (Zeiss). Isolation of fungal was carried out by transferring the fungal structures to the surface of Antibiotic Water Agar $(20 \mathrm{~g} / \mathrm{L}$ agar and chloramphenicol $250 \mathrm{mg} / \mathrm{L}$ ), Potato Dextrose Agar (PDA) (Kasvi), and Malt Extract Agar (MEA) (malt extract $30 \mathrm{~g} / \mathrm{L}$, mycological peptone $5 \mathrm{~g} / \mathrm{L}$ and $15 \mathrm{~g} / \mathrm{L}$ agar, $\mathrm{pH}$ $5.4 \pm 0.2)$. The developed colonies were transferred to PYG agar $(1.25 \mathrm{~g} / \mathrm{L}$ peptone, $1.25 \mathrm{~g} / \mathrm{L}$ yeast extract, $5 \mathrm{~g} / \mathrm{L}$ glucose, $250 \mathrm{mg} / \mathrm{L}$ chloramphenicol, and $18 \mathrm{~g} / \mathrm{L}$ agar) [22] (Figures 2(d)-2(g)).

2.5. DNA Extraction, Amplification, and Sequencing. DNA extraction was performed according to the protocol of Ferrer et al. [31]. Fungi were grown in test tubes containing $10 \mathrm{~mL}$ of potato dextrose broth ( $120 \mathrm{~g}$ potato, $10 \mathrm{~g}$ dextrose, and $1000 \mathrm{~mL}$ distilled water) for 10 days and transferred to Eppendorf tubes $(2 \mathrm{~mL})$ containing $500 \mu \mathrm{L}$ of buffer $(2.5 \mathrm{mg}$ SDS, $7.0 \mathrm{mg} \mathrm{NaCl}, 3.65 \mathrm{mg}$ EDTA, $20 \mathrm{~mL}$ of Tris- $\mathrm{HCl}$ and $100 \mathrm{~mL}$ of DI water, and $5 \mu \mathrm{L}$ of $\beta$-mercaptoethanol). The microtubes were subjected to freezing $\left(-20{ }^{\circ} \mathrm{C}\right)$ and heating $\left(65^{\circ} \mathrm{C}\right.$ for $\left.1 \mathrm{~h}\right)$ in order to rupture the cellular structures. Next, $500 \mu \mathrm{L}$ of a phenol/chloroform/isoamyl alcohol solution (v/v/v: 25/24/1) was added to the microtubes and vortexed until a homogeneous suspension was obtained. The suspension was then centrifuged $(14,000 \mathrm{rpm}, 15 \mathrm{~min})$ and the supernatant was transferred to a new microtube $(1.5 \mathrm{~mL})$. Isopropanol was added to the supernatant in equal volume, and the mixture was homogenized and incubated at $-20^{\circ} \mathrm{C}$ overnight to precipitate the DNA. The precipitated DNA was centrifuged (14,000 rpm for $15 \mathrm{~min}$ ), washed twice with $70 \%$ ethanol, and resuspended in $100 \mu \mathrm{L}$ of sterile water distilled.

Molecular data were gathered by sequencing the ITS region of rDNA according to the procedure of White et al. [32]. The reaction yielded a final volume of $50 \mu \mathrm{L}$, consisting of PCR buffer (10 mM Tris- $\mathrm{HCl}, \mathrm{pH} 8.3,50 \mathrm{mM} \mathrm{KCl})$, $1.5 \mathrm{mM} \mathrm{MgCl} \mathrm{2,} 0.5 \mu \mathrm{M}$ of ITS-1 (5'-TCCGTAGGTGAACCTGCGG-3') and ITS-4 (5'-TCCTCCGCTTATTGATATGC-3'), $200 \mu \mathrm{M}$ dNTPs, $1.5 \mathrm{U}$ Taq DNA polymerase, and $100 \mathrm{ng}$ of fungal DNA. Thermocycling was performed on an Applied Biosystems ProFlex PCR System with initial denaturation at $94^{\circ} \mathrm{C}$ for $5 \mathrm{~min}$, followed by 35 cycles of DNA denaturation at $94^{\circ} \mathrm{C}$ for $1 \mathrm{~min}$, annealing at $55^{\circ} \mathrm{C}$ for $1 \mathrm{~min}$, extension at $72^{\circ} \mathrm{C}$ for $2 \mathrm{~min}$, and a final extension at $72^{\circ} \mathrm{C}$ for $10 \mathrm{~min}$. Two positive controls and one negative control were also tested. Electrophoresis was performed on 1.5\% agarose gel in 1x TBE buffer (100 mM Tris base, $100 \mathrm{mM}$ boric acid, and $2 \mathrm{mM}$ EDTA pH 8.0), plus $10 \mu \mathrm{L} / 100 \mathrm{~mL}$ of Siber Green SYBR ${ }^{\circledR}$ Safe. Amplified fragments were visualized under UV 


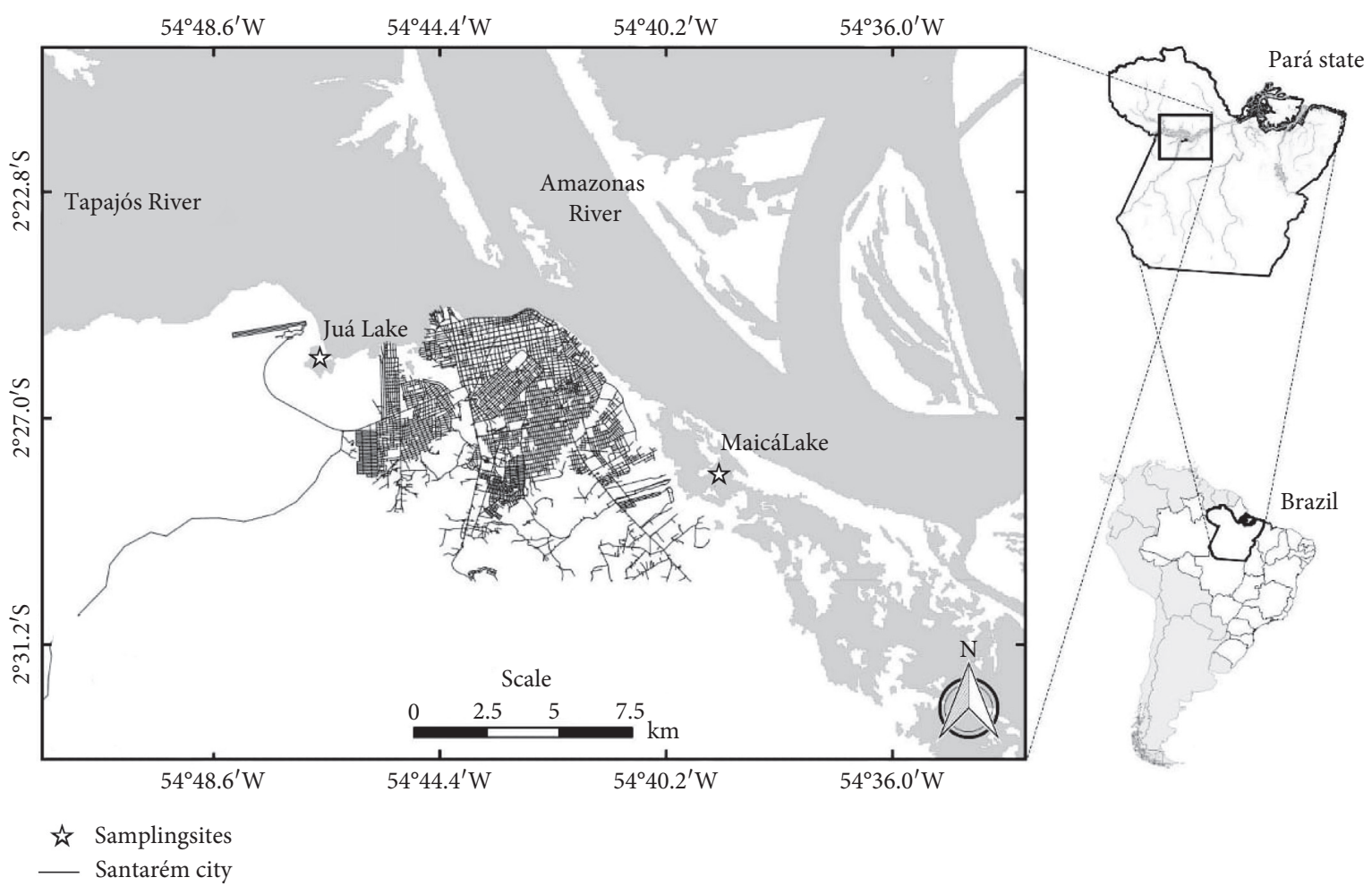

Figure 1: Map of the location of the Lakes Juá and Maicá belonging to the basin of the lower Tapajós River, Santarém, Pará, Brazil (source: Lima, J. L).

light. The amplification products were purified using a solution of polyethylene glycol-PEG (10 g polyethylene glycol $800,7.3 \mathrm{~g} \mathrm{NaCl}$, and $35 \mathrm{~mL}$ of water) as previously described [33]. Similar volumes of the PEG and amplicon solutions were transferred to microtubes $(1.5 \mathrm{~mL})$, homogenized, and incubated $\left(37^{\circ} \mathrm{C}\right.$ for $\left.15 \mathrm{~min}\right)$. The mixture was then centrifuged (15 min at 6,000 rpm), the supernatant was discarded, and the precipitate was washed twice with $70 \%$ ethanol and resuspended in water.

The sequencing reaction was performed using the BigDye $^{\circledR}$ kit (Applied Biosystems). Sequencing was performed on the Seq 3130 Genetic Analyzer (Applied Biosystems). The sequences used in this study were compared and deposited in the GenBank database (Table 1).

2.6. Richness, Diversity, and Equitability of the Fungal Community. The number of individuals was determined for each piece of wood by the presence or absence of a species on it. In this study, an individual was quantified on a persubstrate basis. One individual was counted if it was found on a single piece of wood. However, multiple taxa were usually found to colonize individual substrates. Frequency, richness (species numbers), alpha diversity $(\alpha)$, and similarity of fungi were calculated for each lake. To characterize the diversity of the fungal community, the Shannon-Weaver diversity index $\left(H^{\prime}\right)$ was employed [34]. This index describes diversity with a higher value signifying greater heterogeneity and greater diversity. The following formula was used to perform these calculations:

$$
H^{\prime}=-\sum(p i)^{*}(\log 2 p i)
$$

where $p_{\text {in }}=n i / N, n i=$ is the individual number of $i^{\text {th }}$ taxa, and $N$ is the individual number of all taxa.

In addition, to interpret the Shannon-Weaver index, the evenness index $(E)$ was calculated. This index is the uniformity of copy numbers among taxa. The evenness tends toward 0 when one taxon dominates the community and approaches 1 when the taxa have the same abundance. The index is expressed by the following formula:

$$
E=\frac{H^{\prime}}{\ln S},
$$

where $H^{\prime}$ is the Shannon-Weaver Index based on the number of individuals and $S$ is the number of taxa present in the sample.

To evaluate differences in the fungal communities, the similarity among the samples was calculated using the Sørensen index $\left(S^{\prime}\right)$ with values ranging from 0 (no similarity) to one (absolute similarity). This was calculated using the following formula:

$$
S^{\prime}=\frac{2 c}{a+b},
$$

where $a$ is the total number of taxa collected in Lake Juá, $b$ is the total number of taxa collected in Lake Maicá, and $c$ is the number of common taxa in both lakes. A taxa-area curve was plotted for the two collections to assess the sampling effort. Statistical analyses were performed using the PAST program, version 3.2 [35]. 


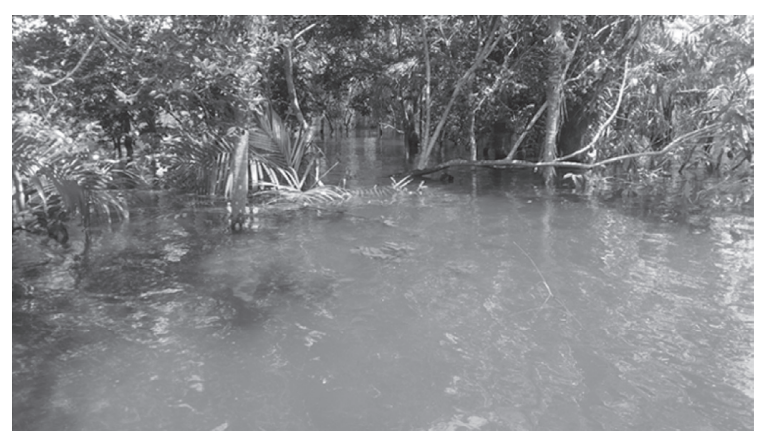

(a)

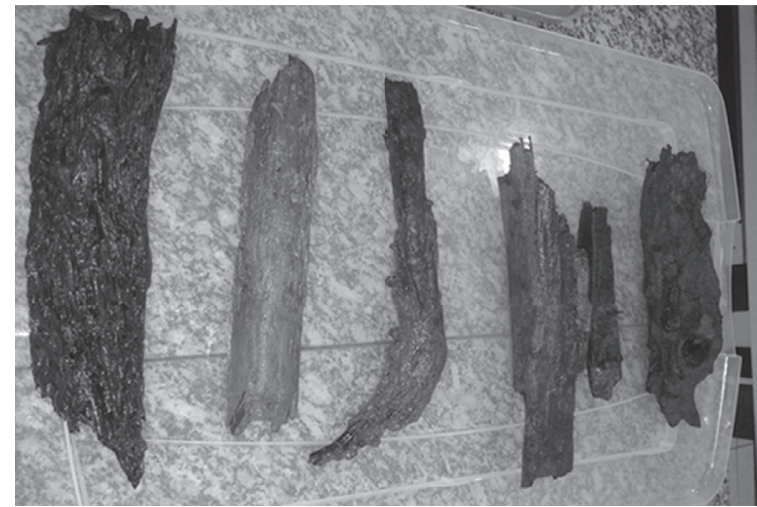

(c)

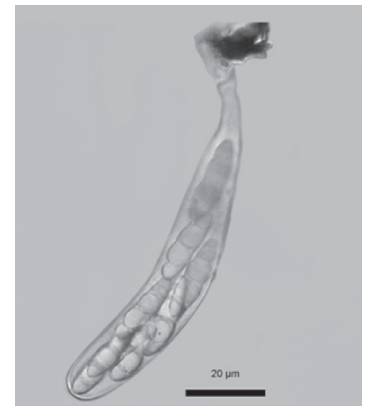

(e)

(f)

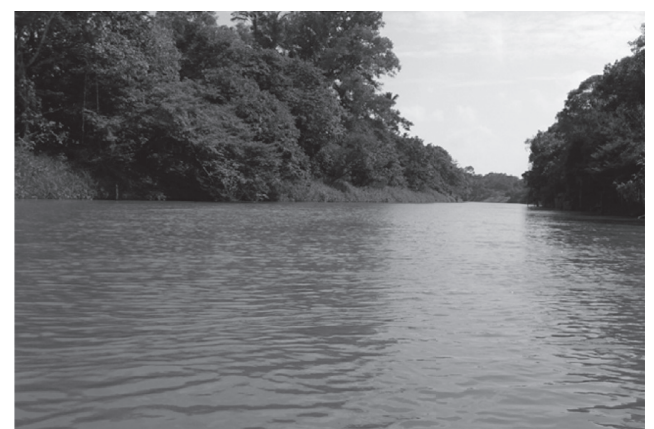

(b)

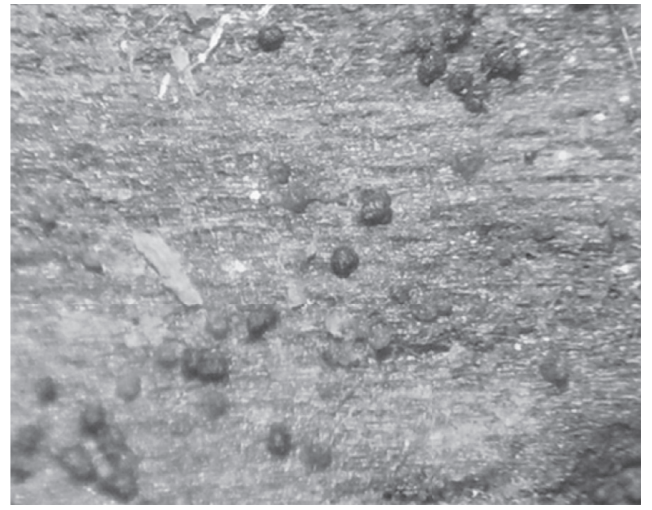

(d)

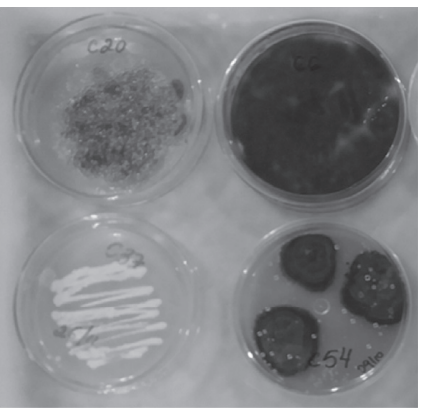

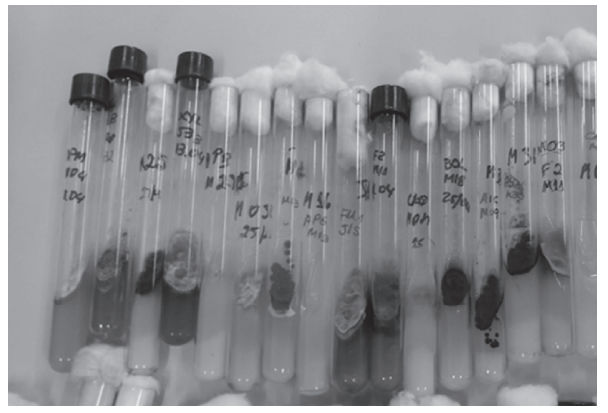

(g)

Figure 2: Collection site of Lake Juá (a). Collection site of Lake Maicá (b). Wood samples (c). Ascomata on a wood surface (d). Asci in the water of Dothideomycetes sp. (e). Colonies on MEA after 14 days at $25^{\circ} \mathrm{C}$ (f). Culture in PYG agar (g).

TABLE 1: Strain code and similarity (ITS Barcode) of 14 taxa isolated from samples of submerged wood collected in the Lakes Juá and Maicá, Santarém, Pará, Brazil.

\begin{tabular}{lccc}
\hline Code/GenBank & Taxon & Accession no. & Similarity (\%) \\
\hline MT017512 & Pseudallescheria boydii & KJ653823.1 & 100 \\
MT017513 & Curvularia clavata & MF038179.1 & MF038179.1 \\
MT017519 & Curvularia clavata & NR_158448.1 & 100 \\
MT017518 & Curvularia petersonii & MN826823.1 & NR_164383.1 \\
MT017514 & Cladosporium holotolerans & KT823783.1 & 97.15 \\
MT017515 & Simplicidiella nigra & EU770223.1 & 91.3 \\
MT017516 & Jattaea sp. & GU827483.1 & 90.46 \\
MT017517 & Jattaea sp. & MH857954.1 & 90.32 \\
MT017520 & Bionectria sp. & JN882257.1 & 99.41 \\
MT017523 & Gonytrichum macroladum & KP637162.1 & 98.34 \\
MT017524 & Fusarium solani & NR_111278.1 & 99.12 \\
MT017525 & Helicascus thalassioideus & KR817246.1 \\
MT017522 & Cladophialophora saturnica & 90.02 \\
MT017521 & Calosphaeriales sp. & 99.46
\end{tabular}


In order to determine whether the sample size was sufficient to describe the diversity of the collection sites, the accumulation curve of the taxa found in the samples of submerged wood decomposed in the two lakes under study was analyzed by the ratio between the number of new taxa and the number of wood samples.

\section{Results}

3.1. Physicochemical Characteristics. In order to characterize the aquatic environments in this study, physicochemical analyses of the waters of the Lakes Juá and Maicá were performed at the time of sampling of wood samples. Table 2 lists the values of the parameters.

3.2. Sample Size. The accumulation curves obtained for the samples from Lakes Juá and Maicá show that the number of taxa does not asymptote, suggesting that we have not adequately captured the freshwater fungal species (Figure 3) and additional collections may be necessary.

3.3. Identification of Fungi. Morphologically, 23 different taxa were identified in the Lake Juá, with $43.5 \%(n=10)$ being sexual (5 Dothideomycetes and 5 Sordariomycetes) and $56.5 \%(n=13)$ being asexual. In the Lake Maicá, 26 taxa were identified morphologically, of which $65.4 \%(n=17)$ were sexual (4 Dothideomycetes and 13 Sordariomycetes), and $34.6 \%(n=9)$ were asexual. We carried out DNA analysis studies with only fourteen taxa (Table 1). It was not possible to investigate all taxa because most of them were uncultivated fungi that did not allow DNA extraction. ITS sequence data were successfully obtained and used to corroborate morphological identification (Table 3).

3.4. Richness, Diversity, and Equitability. In the Lake Juá, the diversity $\left(H^{\prime}\right)$ and equitability $(E)$ indices reached 2.65 and 0.616255 , respectively. In this period, the five most frequent taxa were Xylomyces giganteus (18\%), Pseudoxylomyces elegans (11\%), Pleosporaceae MT017518, Fluviatispora sp., and Teratosphaeriaceae MT017515 (9\%). In the Lake Maicá, the diversity and equitability indices reached 2.82 and 0.643588 , respectively. At this site, the most frequent taxa were Thielavia sp. (11\%), Longicollum biappendiculatum (8\%), Submersisphaeria sp., Aquaticola sp., and Morosphaeriaceae MT017515 (7\%). The Sørensen index of the fungal communities between the two lakes studied was 0.3673. Eight taxa occurred in both environments. Information on the richness, diversity, and equitability of the taxa observed in the two lakes is described in Table 4.

\section{Discussion}

In the present study, we described the fungal diversity associated with the decomposition of wood in lakes belonging to the Tapajós River (PA, Brazil). This is an important study because it is the first to describe the diversity of these organisms in the lakes of the Tapajós River region. In the
TABLE 2: Characterization of the physicochemical parameters of the water of the Lakes Juá and Maicá, Santarém, Pará, Brazil, during the collections.

\begin{tabular}{lcc}
\hline Parameters & Lake Juá & Lake Maicá \\
\hline $\mathrm{pH}$ & $4.9 \pm 0.2$ & $6.7 \pm 0.2$ \\
Electrical conductivity $(\mu \mathrm{S})$ & $9.3 \pm 0.2$ & $42 \pm 0.2$ \\
Water temperature $\left({ }^{\circ} \mathrm{C}\right)$ & $30 \pm 0.1$ & $30 \pm 0.1$ \\
Total $\mathrm{O}_{2}(\mathrm{mg} / \mathrm{L})$ & $7.8 \pm 0.1$ & $6.5 \pm 0.1$ \\
Turbidity $(\mathrm{NTU})$ & $30 \pm 0.1$ & $26.9 \pm 0.1$ \\
\hline
\end{tabular}

experimental conditions, both lakes presented high diversity and few similarities among the taxa.

The Lake Juá had a low $\mathrm{pH}(4.9 \pm 0.2)$ and low electrical conductivity $(9.3 \pm 0.2 \mu \mathrm{S})$. This was expected because Lake Juá is influenced by the Tapajós River [15, 36]. Its turbidity was $30 \pm 0.1 \mathrm{NTU}$, perhaps due to the direct interference of anthropic actions such as wastewater disposal due to the proximity to the urban area of Santarém. The Lake Maicá had neutral $\mathrm{pH}(6.7 \pm 0.2)$ and high electrical conductivity $(42 \pm 0.2 \mu \mathrm{S})$. This may be due to the influence of the Amazon River during the flood season [14]. This river has an alkaline $\mathrm{pH}$, high electrical conductivity, and high turbidity due to the large amount of sediment coming from the Andean regions $[15,16]$. It is important to know the characteristics of the water in aquatic fungal diversity studies because previous studies have shown that factors such as $\mathrm{pH}$, nutrients, substrate type, river geomorphology, and seasonality affect the fungal communities in aquatic environments [37-39].

The accumulation curve showed approximate stability after the collection of 20 to 25 samples from each lake studied (Juá and Maicá, respectively). Luo et al. [40] collected 100 samples of grass and bamboo from the Lake Dianchi in Thailand during four sampling events over a oneyear period and reached asymptote in 50 and 70 samples. $\mathrm{Hu}$ et al. [41] collected 100 samples from a dammed lake and 90 samples in a stream, obtaining the stabilization of the curve in 60 and 80 samples, respectively. Cortez [28] collected 60 fragments of submerged wood in a lake in the region of Iranduba (Amazonas, Brazil) in two periods of the seasonal cycle, obtaining a plateau of species in 15 samples collected in the nonrainy period. In this study, 30 samples per lake were collected and appeared sufficient to near a plateau for local diversity.

At the Lakes Juá and Maicá, we observed 23 and 26 taxa, respectively. The number of unique taxa was 15 and 18 in the Lakes Juá and Maicá, respectively (Table 3). These results are similar to those observed by Cortez [28], who identified 25 taxa in a black water lake in Amazonas State. When compared to other works [41-43], the total number of taxa in this study was lower. This may be related to differences in the number of samples per period, the quantity of collections made, and the types of environments studied. In addition, previous studies have stated that physicochemical factors of water play an important role in the richness of ascomycetes present in freshwater and may be a factor in these lakes [44].

The Lake Juá presented greater richness of asexual fungi (56.5\%) and Maicá of sexual fungi (65.4\%). In the Lake Juá, 


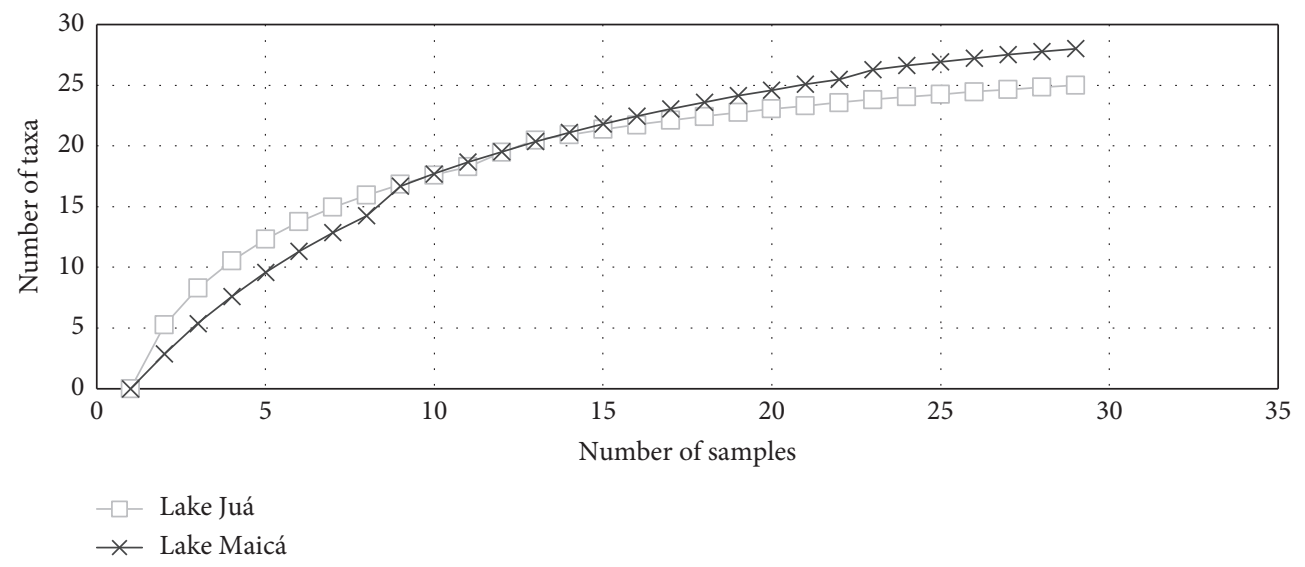

Figure 3: Accumulation curve of the number of fungi taxa found in relation to the sampling effort of collecting submerged fragments of decomposed wood in the Lakes Juá and Maicá, Santarém, Pará, Brazil.

Table 3: Frequency of taxa observed in samples of submerged wood collected in the Lakes Juá and Maicá, Santarém, Pará, Brazil.

\begin{tabular}{|c|c|c|c|c|}
\hline \multirow{2}{*}{ Taxa } & \multicolumn{2}{|c|}{ Lake Juá } & \multicolumn{2}{|c|}{ Lake Maicá } \\
\hline & FAB & FRE (\%) & FAB & FRE (\%) \\
\hline Xylomyces giganteus Goh, W. H. Ho, K. D. Hyde \& K. M. Tsui & 18 & 15 & 0 & 0 \\
\hline Pseudoxylomyces elegans (Goh, W. H. Ho, K. D. Hyde \& K. M. Tsui), Kaz. Tanaka \& Hiray & 13 & 11 & 0 & 0 \\
\hline Teratosphaeriaceae MT017515** & 11 & 9 & 0 & 0 \\
\hline Pleosporaceae MT017518** & 11 & 9 & 0 & 0 \\
\hline Fluviatispora sp. & 11 & 9 & 0 & 0 \\
\hline Cancellidium applanatum Tubaki & 9 & 7 & 1 & 1 \\
\hline Cumulospora sp.* & 7 & 6 & 0 & 0 \\
\hline Cordana terrestris (Timonin) M. Hern.-Rest., Gené \& Guarro & 7 & 6 & 0 & 0 \\
\hline Chloridium sp. & 5 & 4 & 5 & 6 \\
\hline Lasiosphaeria sp. & 4 & 3 & 0 & 0 \\
\hline Jobellisia sp.* & 4 & 3 & 0 & 0 \\
\hline Aquaticola sp. & 3 & 2 & 6 & 7 \\
\hline Taeniolella sp.* & 3 & 2 & 2 & 2 \\
\hline Morosphaeriaceae MT017525** & 2 & 2 & 6 & 7 \\
\hline Microascaceae MT017512** & 2 & 2 & 0 & 0 \\
\hline Diaporthales sp.1 MT017516; MT017517** & 2 & 2 & 0 & 0 \\
\hline Gonytrichum sp. MT017523*** & 2 & 2 & 0 & 0 \\
\hline Monodictys sp. & 2 & 2 & 0 & 0 \\
\hline Unidentified Pleosporales 3 & 1 & 1 & 5 & 6 \\
\hline Acrogenospora sphaerocephala, (Berk. \& Broome) M. B. Ellis & 1 & 1 & 1 & 1 \\
\hline Cladophialophora sp. MT017522** & 1 & 1 & 0 & 0 \\
\hline Curvularia sp. MT017513; MT017519** B. L. Jain & 1 & 1 & 1 & 1 \\
\hline Stilbella sp.* & 1 & 1 & 0 & 0 \\
\hline Dothideomycetes sp. & 0 & 0 & 3 & 4 \\
\hline Dothideomycetes sp.1 & 0 & 0 & 3 & 4 \\
\hline Thielavia sp.* & 0 & 0 & 9 & 11 \\
\hline Longicollum biappendiculatum Zelski, F. R. Barbosa, Raja, A. N. Mill \& Shearer & 0 & 0 & 7 & 8 \\
\hline Submersisphaeria sp. & 0 & 0 & 6 & 7 \\
\hline Annulatascus-like sp. & 0 & 0 & 5 & 6 \\
\hline Savoryellales sp. & 0 & 0 & 3 & 4 \\
\hline Aniptodera sp. & 0 & 0 & 2 & 2 \\
\hline Pseudohalonectria-like sp. ${ }^{*}$ & 0 & 0 & 2 & 2 \\
\hline Annulatascaceae-like sp. & 0 & 0 & 2 & 2 \\
\hline Ophioceras-like sp. ${ }^{*}$ & 0 & 0 & 2 & 2 \\
\hline Sordariomycetes sp. MT017521** & 0 & 0 & 2 & 2 \\
\hline Nectriaceae sp. MT017520** & 0 & 0 & 2 & 2 \\
\hline Cladosporiaceae MT017514** & 0 & 0 & 2 & 2 \\
\hline Nectriaceae MT017524** & 0 & 0 & 1 & 1 \\
\hline Potamomyces armatisporus K. D. Hyde & 0 & 0 & 2 & 2 \\
\hline Helicosporium sp. & 0 & 0 & 1 & 1 \\
\hline Sporoschisma sp. & 0 & 0 & 3 & 4 \\
\hline TOTAL & 121 & 100 & 84 & 100 \\
\hline
\end{tabular}

${ }^{*}$ First records for the Brazilian Amazon. FAB: absolute frequency; FRE: relative frequency. ${ }^{* *}$ ITS Sequence obtained. 
TABle 4: Comparison of diversity (indices: $H, E$, and $S$ of the fungi community present in the samples of the Lakes Juá and Maicá, Santarém, Pará, Brazil.

\begin{tabular}{lcc}
\hline Sampling & Lake Juá October 2017 & Lake Maicá November 2017 \\
\hline Sample size & 30 & 30 \\
Number of ascomycetes (sexual) & 51 & 67 \\
Number of ascomycetes (asexual) & 70 & 14 \\
Average number of taxa per sample & 4.0 & 2.8 \\
Singleton taxa & 15 & 18 \\
Overlap in both lakes & 8 & Thielavia sp., 9 (11\%) \\
Five most common taxa & Xylomyces giganteus, 18 (18\%) & \\
& Pseudoxylomyces elegans 13 (11\%) & Submersisphaeria sp. 6 (7\%) \\
& & Aquaticola sp. 6 (7\%) \\
& Pleosporaceae MT017518 11 (9\%) & Morosphaeriaceae MT017525 6 (7\%) \\
Species richness $(R)$ & Fluviatispora sp., 11 (9\%) & 26 \\
Shannon-Weaver $\left(H^{\prime}\right)$ & Teratosphaeriaceae MT017515, 11 (9\%) & 2.82 \\
Evenness $(E)$ & 23 & 0.643588 \\
Sørensen $\left(S^{\prime}\right)$ & 2.65 & 0.616255
\end{tabular}

this may be related to the influence of a stream that drains into this environment, supporting the increase of this taxon in the lake $[45,46]$. In the Lake Maicá, the sexual species richness was greater. These results resemble those reported by $\mathrm{Hu}$ et al. [41], who found greater sexual richness in a lentic environment. Cortez [28] also found similar results and attributed these results to pluviometric action because rainwater can carry fungi from soil or vegetation to the lake.

The five most frequent taxa in the Lake Juá were Pseudoxylomyces elegans, Xylomyces giganteus, Pleosporaceae MT017518, Fluviatispora sp., and Teratosphaeriaceae MT017515. In the Lake Maicá, the five most frequent taxa were Thielavia sp., Longicollum biappendiculatum, Submersisphaeria sp., Aquaticola sp., and Morosphaeriaceae MT017525. Aquaticola sp. and Longicollum biappendiculatum were the most frequent taxa described by Cortez [28]. Abdel-Aziz [43] in a study on submerged stems of Phragmites australis (Cav.) Trin. ex Steud listed seven species that were common in this study (Aniptodera sp., Annulatascuslike, Aquaticola sp., Ophioceras sp., Pseudohalonectria sp., Thielavia sp., and Monodictys-like). Raja et al. [42], in freshwater environments of the Florida Peninsula, shared five taxa (Aniptodera sp., Ophioceras sp., Submersisphaeria aquatica, Fluviatispora reticulata, and Longicollum biappendiculatum). It was observed that these taxa occurred in both lentic and lotic environments. According to Shearer et al. [24], the composition of freshwater ascomycetes species is similar between Florida, tropical South America (Peru), and tropical Southeast Asia.

Cancellidium applanatum, found in Lake Juá and Maicá, was also reported by Zelski et al. [22] in a survey of ascomycetes in wood submerged in freshwater habitats in Peru. This species is considered a generalist and can occur in herbaceous and woody substrates of lotic and lentic habitats. This species, as well as Monodictys sp., can be considered resistant to dry periods [47], and its presence is not surprising considering that the Lake Juá also undergoes considerable periods of drought. In addition, Acrogenospora sphaerocephala has recently been reported on leaf material in rivers and streams in the Caatinga biome as well as in submerged wood in a lake in Manaus, Amazonas [5, 28]. Nine taxa were identified as new records for the Brazilian Amazon, as shown in Table 1.

The Lakes Juá and Maicá presented a diversity of $\mathrm{H}^{\prime}$ index $=2.65$ and 2.82, respectively. Hu et al. [41] in Thailand compared an artificial lake and a stream obtaining a diversity index of 2.34 and 3.68, respectively, indicating that factors such as the composition of riparian forest, damming of rivers, and anthropogenic actions may affect the community and the diversity of fungi in freshwater habitats. Cortez [28] studied the diversity in a lake in the state of Amazonas, making seasonal comparisons, and obtained indices of 2.60 in the rainy season and 2.13 in the nonrainy season. This study inferred that seasonality may affect fungal diversity. In the Nile, Abdel-Aziz [43] also performed seasonal comparisons, with indices of 3.08 and 2.44 for winter and summer, respectively. Hyde et al. [48] emphasized that the number of taxa per wood sample is higher in the tropics than in temperate habitats. According to Graça et al. [49], the variation in low diversity rates in tropical and subtropical areas may be related to ecological and methodological issues. The diversity indexes of the present work are similar to those found in other lentic environments (mean 2.8 ) and corroborate the assertion that diversity in lotic environments is greater (mean 4.60) [41, 50-52].

Sørensen's similarity index (0.3673) revealed low similarity among the studied lakes. This may be due to the structural and physicochemical differences found during the study that are responsible for the composition of the mycota in aquatic ecosystems [37, 38, 53]. According to Leff [54], the microbial composition is affected in streams and rivers by the unidirectional flow of water (which is reflected in organisms' life strategies), mixing and aeration of water, and the importance of allochthonous materials.

Studies on fungi that decompose submerged wood in aquatic environments are lacking in the Amazon region. Thus, the present work was motivated to contribute to the knowledge of the diversity of aquatic fungi in this region. 
The results show that there is a rich and balanced diversity. This study provides more insight into the dynamics of freshwater fungi in clear water habitats and indicates how the community is distributed in the Amazonian lakes. It is noteworthy that further studies are needed to strengthen this line of research and increase available information on biogeography, ecology, and taxonomy of freshwater ascomycetes species in the Brazilian Amazon.

\section{Data Availability}

The data used to support the findings of this study are available from the corresponding author upon request.

\section{Conflicts of Interest}

The authors declare that they have no conflicts of interest.

\section{Acknowledgments}

The authors would like to thank the Universidade Federal do Oeste do Pará-UFOPA and the Laboratório de Micologia/ Instituto Nacional de Pesquisas da Amazônia-INPA for provision of laboratory facilities. Laboratório de Tecnologias de DNA-UFAM responsible for DNA sequencing samples. We thank Prof. Dr. Carlos Ivan Vildoso and Dr. Huzefa Raja for their collaboration. This study was funded in part by the Coordenação de Aperfeiçoamento de Pessoal de Nível Superior-Brasil (CAPES) (finance code 001”d).

\section{References}

[1] M. K. M. Wong, T.-K. Goh, I. J. Hodgkiss et al., "Role of fungi in freshwater ecosystems," Biodiversity and Conservation, vol. 7, no. 9, pp. 1187-1206, 1998.

[2] E. B. G. Jones and K.-L. Pang, "Tropical aquatic fungi," Biodiversity and Conservation, vol. 21, no. 9, pp. 2403-2423, 2012.

[3] H.-P. Grossart and K. Rojas-jimenez, "Aquatic fungi: targeting the forgotten in microbial ecology," Current Opinion in Microbiology, vol. 31, pp. 140-145, 2016.

[4] V. Gulis, K. Kuehn, and K. Suberkropp, "The role of fungi in carbon and nitrogen cycles in freshwater ecosystems," in Fungi in Biogeochemical Cycles, G. M. Gadd, Ed., pp. 404-435, Cambridge University Press, Cambridge, UK, 2006.

[5] F. R. Barbosa, H. A. Raja, C. A. Shearer, and L. F. P. Gusmão, "Some freshwater fungi from the Brazilian semi-arid region, including two new species of hyphomycetes," Cryptogamie, Mycologie, vol. 34, no. 3, pp. 243-258, 2013.

[6] P. O. Fiuza, L. A. Costa, A. O. Medeiros, V. Gulis, L. F. P. Gusmão, and P. Gusmão, "Diversity of freshwater hyphomycetes associated with leaf litter of Calophyllum brasiliense in streams of the semiarid region of Brazil," $M y$ cological Progress, vol. 18, no. 7, pp. 907-920, 2019.

[7] M. Blackwell, "The Fungi: 1, 2, 3 . . 5.1 million species?" American Journal of Botany, vol. 98, no. 3, pp. 426-438, 2011.

[8] X.-Y. Liu, D. Udayanga, Z.-L. Luo et al., "Backbone tree for Chaetothyriales with four new species of Minimelanolocus from aquatic habitats," Fungal Biology, vol. 119, no. 11, pp. 1046-1062, 2015.

[9] A. Swe, R. Jeewon, S. B. Pointing, and K. D. Hyde, "Diversity and abundance of nematode-trapping fungi from decaying litter in terrestrial, freshwater and mangrove habitats," Biodiversity and Conservation, vol. 18, no. 6, pp. 1695-1714, 2009.

[10] C. A. Shearer and H. A. Raja, Freshwater Ascomycetes, Springer, Berlin, Germany, 2010, http://fungi.life.illinois.edu/.

[11] S. Hongsanan, S. S. N. Maharachchikumbura, and K. D. Hyde, "An updated phylogeny of Sordariomycetes based on phylogenetic and molecular clock evidence," Fungal Diversity, vol. 84, no. 3, pp. 25-41, 2017.

[12] H. Zhang, W. Dong, K. D. Hyde et al., "Towards a natural classification of Annulatascaceae-like taxa: introducing Atractosporales ord. nov. and six new families," Fungal Diversity, vol. 85, no. 1, pp. 75-110, 2017.

[13] F. Aprile, A. J. Darwich, G. W. Siqueira, and F. R. R. Santos, "Application of hydrological and limnological studies on building model for water circulation of meromictic black water lakes at the central," International Research Journal of Environment Sciences, vol. 2, no. 7, pp. 58-63, 2013.

[14] H. Sioli, "The Amazon: limnology and landscape ecology of a migth tropical river and it's basin," Monographie Biologicae, Springer Science \& Business Media, vol. 56Berlin, Germany, , 1983.

[15] K. O. Konhauser, W. S. Fyfe, and B. I. Kronberg, "Multielement chemistry of some Amazonian waters and soils," Chemical Geology, vol. 111, no. 1-4, pp. 155-175, 1994.

[16] A.-M. Aucour, F.-X. Tao, P. Moreira-turcq, P. Seyler, S. Sheppard, and M. F. Benedetti, "The Amazon River: behaviour of metals ( $\mathrm{Fe}, \mathrm{Al}, \mathrm{Mn}$ ) and dissolved organic matter in the initial mixing at the Rio Negro/Solimões confluence," Chemical Geology, vol. 197, no. 1-4, pp. 271-285, 2003.

[17] E. M. Latrubesse, E. Y. Arima, T. Dunne et al., "Damming the rivers of the Amazon basin," Nature, vol. 546, no. 7658, pp. 363-369, 2017.

[18] E. Chauvet, J. Cornut, K. R. Sridhar, M.-A. Selosse, and F. Bärlocher, "Beyond the water column: aquatic hyphomycetes outside their preferred habitat," Fungal Ecology, vol. 19, pp. 112-127, 2016.

[19] T. Matsushima, Matsushima Mycological Memoirs (N. 7, Kobe, Kobe, Hyogo, Japan, 1993.

[20] S. E. Zelski, H. A. Raja, A. N. Miller, F. R. Barbosa, L. F. P. Gusmão, and C. A. Shearer, "Longicollum biappendiculatum gen. et sp . nov ., a new freshwater ascomycete from the Neotropics," Mycosphere, vol. 5, no. 2, pp. 539-545, 2011.

[21] S. Zelski, H. A. Raja, A. N. Miller, and C. A. Shearer, "Chaetorostrum quincemilensis, gen. et sp. nov., a new freshwater ascomycete and its Taeniolella-like anamorph from Peru," Mycosphere, vol. 2, no. 5, pp. 593-600, 2011.

[22] S. E. Zelski, J. A. Balto, C. Do, H. A. Raja, A. N. Miller, and C. A. Shearer, "Phylogeny and morphology of dematiaceous freshwater microfungi from Perú," IMA Fungus, vol. 5, no. 2, pp. 425-438, 2014.

[23] S. E. Zelski, H. A. Raja, A. N. Miller, and C. A. Shearer, "Conioscypha peruviana sp. nov., its phylogenetic placement based on 28S rRNA gene, and a report of Conioscypha gracilis comb. nov. from Peru," Mycoscience, vol. 56, no. 3, pp. 319-325, 2015.

[24] C. A. Shearer, S. E. Zelski, H. A. Raja, J. P. Schmit, A. N. Miller, and J. P. Janovec, "Distributional patterns of freshwater ascomycetes communities along an Andes to Amazon elevational gradient in Peru," Biodiversity and Conservation, vol. 24, no. 8, pp. 1877-1897, 2015.

[25] R. F. d. Santos, H. M. P. Sotão, J. S. Monteiro, L. F. P. Gusmão, and A. H. Gutiérrez, "Conidial fungi associated with leaf litter of red cedar (Cedrela odorata) in Belém, Pará (eastern Brazilian Amazon)," Acta Amazonica, vol. 48, no. 3, pp. 230-238, 2018. 
[26] J. S. Monteiro and L. F. P. Gusmão, “An emendation of Fusticeps and two new species from the Brazilian Amazon Forest," Mycotaxon, vol. 123, no. 1, pp. 431-437, 2013.

[27] P. O. Fiuza, B. M. de Paiva Ottoni-Boldrini, J. S. Monteiro, N. R. Catena, N. Hamada, and L. F. P. Gusmão, "First records of ingoldian fungi from the Brazilian Amazon," Brazilian Journal of Botany, vol. 38, no. 3, pp. 615-621, 2015.

[28] A. C. A. Cortez, Influência da sazonalidade e do modo de coleta na diversidade de fungos decompositores de madeira submersa de ambientes aquáticos da região amazônica (Tese de doutorado), Universidade Federal do Amazonas, Manaus, Amazonas, Brasil, 2016, https://tede.ufam.edu.br/bitstream/ tede/5632/5/Tese\%20-\%20Ana\%20Claudia\%20A.\%20Cortez. pdf.

[29] L. Cai, K. D. Hyde, and C. K. M. Tsui, "Genera of freshwater fungi," in The University of Hong Kong, K. D. Hyde, Ed., Fungal diversity Press, San Diego, CA, USA, 1st edition, 2006.

[30] K. Seifert and W. Gams, "The genera of hyphomycetes," Persoonia, vol. 27, pp. 119-129, 2011.

[31] C. Ferrer, F. Colom, S. Frasés, E. Mulet, J. L. Abad, and J. L. Alió, "Detection and identification of fungal pathogens by PCR and by ITS2 and 5.8S ribosomal DNA typing in ocular infections," Journal of Clinical Microbiology, vol. 39, pp. 2873-2879, 2001.

[32] T. J. White, T. Bruns, S. Lee, and J. Taylor, "Amplification and direct sequencing of fungal ribosomal RNA genes for phylogenetics," in PCR Protocols: A Guide to Methods and Applications, N. Innis, D. Gelfand, J. Sninsky, and T. White, Eds., pp. 315-322, Academic Press, Cambridge, MA, USA, 1990.

[33] I. S. Dun and F. R. Blattner, "Charons 36 to 40: multi enzyone, high capacity, recombination deficient replacement vectors with polylinkers and ploystuffers," Nucleic Acids Research, vol. 15, no. 6, pp. 2677-2698, 1987.

[34] C. J. Krebs, "Ecological methodology," in University of British Columbia, , Harper \& Row, Manhattan, NY, USA, 2rd. edition, 1989.

[35] O. Hammer, D. A. T. Harper, and P. D. Ryan, "PAST: paleontological statistics software package for education and data analysis," Paleontologia Electronica, vol. 4, no. 1, pp. 1-9, 2001.

[36] W. P. Duncan and M. N. Fernandes, "Physiochemical characterization of the white, black, and clearwater rivers of the Amazon Basin and its implications on the distribution of freshwater stingrays (Chondrichthyes, Potamotrygonidae)," Pan-American Journal of Aquatic Sciences, vol. 5, no. 3, pp. 454-464, 2010.

[37] S. Duarte, F. Bärlocher, J. Trabulo, F. Cássio, and C. Pascoal, "Stream-dwelling fungal decomposer communities along a gradient of eutrophication unraveled by 454 pyrosequencing," Fungal Diversity, vol. 70, no. 1, pp. 127-148, 2014.

[38] J. Heino, M. Tolkkinen, A. M. Pirttilä, H. Aisala, and H. Mykrä, "Microbial diversity and community-environment relationships in boreal streams," Journal of Biogeography, vol. 41, no. 12, pp. 2234-2244, 2014.

[39] P. Song, S. Tanabe, R. Yi, M. Kagami, X. Liu, and S. Ban, "Fungal community structure at pelagic and littoral sites in Lake Biwa determined with high-throughput sequencing," Limnology, vol. 19, no. 2, pp. 241-251, 2018.

[40] J. Luo, J. F. Yin, L. Cai, K. Q. Zhang, and K. D. Hyde, "Freshwater fungi in Lake Dianchi, a heavily polluted lake in Yunnan, China," Fungal Diversity, vol. 16, pp. 93-112, 2004.

[41] D. Hu, L. Cai, H. Chen, A. H. Bahkali, and K. D. Hyde, "Fungal diversity on submerged wood in a tropical stream and an artificial lake," Biodiversity and Conservation, vol. 19, no. 13, pp. 3799-3808, 2010.

[42] H. A. Raja, J. P. Schmit, and C. A. Shearer, "Latitudinal, habitat and substrate distribution patterns of freshwater ascomycetes in the Florida Peninsula," Biodiversity and Conservation, vol. 18, no. 2, pp. 419-455, 2009.

[43] F. A. Abdel-Aziz, "Freshwater fungi from the river nile, Egypt," Mycosphere, vol. 7, no. 5, pp. 741-756, 2016.

[44] M. A. S. Graça, V. Ferreira, C. Canhoto et al., "A conceptual model of litter breakdown in low order streams," International Review of Hydrobiology, vol. 100, no. 1, pp. 1-12, 2015.

[45] F. Bärloche and B. Kendrick, "Dynamics of the fungal population on leaves in a stream," Journal ofEcology, vol. 62, no. 3, pp. 761-779, 1974.

[46] J. Webster and E. Descals, "Morphology, distribution and ecology of conidial fungi in freshwater habitats," in Biology of Conidial Fungi, M. Dekker, Ed., vol. 1, pp. 459-468, Academic Press, Cambridge, MA, USA, 1981.

[47] K. D. Hyde, S. Fryar, Q. Tian, A. H. Bahkali, and J. Xu, "Lignicolous freshwater fungi along a north-south latitudinal gradient in the Asian/Australian region; can we predict the impact of global warming on biodiversity and function?" Fungal Ecology, vol. 19, pp. 190-200, 2016.

[48] K. D. Hyde, S. Hongsanan, R. Jeewon et al., "Fungal diversity notes 367-490: taxonomic and phylogenetic contributions to fungal taxa," Fungal Diversity, vol. 80, no. 1, pp. 1-270, 2016.

[49] M. A. S. Graça, K. Hyde, and E. Chauvet, "Aquatic hyphomycetes and litter decomposition in tropical - subtropical low order streams," Fungal Ecology, vol. 19, pp. 182-189, 2016.

[50] K. D. Hyde and T. K. Goh, "Fungi on submerged wood In lake barrine, north queensland, Australia," Mycological Research, vol. 102, no. 6, pp. 739-749, 1998.

[51] T. K. Goh and K. D. Hyde, "Fungi on submerged wood and bamboo in the Plover Cove," Fungal Diversity, vol. 3, pp. $57-85,1999$.

[52] W. H. Ho, K. D. Hyde, and I. J. Hodgkiss, "Fungal communities on submerged wood from streams in Brunei, Hong Kong, and Malaysia," Mycological Research, vol. 105, no. 12, pp. 1492-1501, 2001.

[53] C. Wurzbacher, S. Rösel, A. Rychła, and H. P. Grossart, "Importance of saprotrophic freshwater fungi for pollen degradation," Plos One, vol. 9, no. 4, pp. 1-12, 2014.

[54] L. G. Leff, "Freshwater habitats," Encyclopedia of Microbiology, Elsevier, vol. 4e, pp. 1-4, , Amsterdam, Netherlands, 2019. 